https:// doi.org/10.15407/mineraljournal.43.01.016

UDC $550.4: 549.6(477)$

S.B. Lobach-Zhuchenko, DrSc (Geology \& Mineralogy), Prof., Chief Research Fellow Institute of Precambrian Geology and Geochronology of RAS

2, Makarova Emb., St. Petersburg, Russia, 199034

E-mail: slobach-zhuchenko@mail.ru; ScopusID: 6601977762

Yu.S. Egorova, PhD (Geology \& Mineralogy), Research Fellow Institute of Precambrian Geology and Geochronology of RAS

2, Makarova Emb., St. Petersburg, Russia, 199034

E-mail: axoxyx2014@gmail.com; https:/ / orcid.org/0000-0001-5008-6867

S.G. Skublov, DrSc (Geology \& Mineralogy), Prof., Chief Research Fellow

Institute of Precambrian Geology and Geochronology of RAS

2, Makarova Emb., St. Petersburg, Russia, 199034

Saint Petersburg Mining University

2, 21st Line, St. Petersburg, Russia, 199106

E-mail: skublov@yandex.ru; http:/ / orcid.org/0000-0002-5227-4260

V.V. Sukach, DrSc (Geology), Head of Department

M.P. Semenenko Institute of Geochemistry, Mineralogy and Ore Formation of NAS of Ukraine

34, Acad. Palladin Ave., Kyiv, Ukraine, 03142

E-mail: svital@ukr.net; ScopusID: 56287291600

O.L. Galankina, PhD (Geology \& Mineralogy), Senior Research Fellow

Institute of Precambrian Geology and Geochronology of RAS

2, Makarova Emb., St. Petersburg, Russia, 199034

E-mail: galankinaol@mail.ru; ScopusID: 7801578217

\title{
IRON- AND NICKEL ENRICHED OLIVINE FROM PHLOGOPITE HARZBURGITE OF THE BUG GRANULITE COMPLEX (UKRAINIAN SHIELD)
}

\begin{abstract}
An abundance of the trace elements has been determined in olivine of the Achaean spinel-bearing phlogopite harzburgite enclave (sample UR17/2) from the Bug granulite complex of the Ukrainian Shield by SIMS analysis. Major elements were analyzed in the olivine by SEM-EDS and EPMA analysis. The olivine shows a homogeneous chemical composition: $\mathrm{MgO}-45.20$ 45.64 wt. \%, $\mathrm{FeO}-13.66-14.23$ wt.\%, with $\mathrm{Fo}_{85-86}$ and $\mathrm{Fe} / \mathrm{Mn}$ ratio of 68.3-68.6 which corresponds to the ratio of 60-70 in olivine of peridotites. Ni content in the UR17/2 olivine ranges from 4730 to 5612 ppm, which is higher than in olivine from mantle peridotites, high magnesium OIB and Hawaiian picrites. The olivine has average content of Ti - 20.6 ppm, Nb$0.03 \mathrm{ppm}, \mathrm{Zr}-0.32-0.60 \mathrm{ppm}$, the low total REE (0.1-0.5 ppm). The olivine crystallization temperature, calculated using an Al-in-olivine thermometer, corresponds to $\sim 900{ }^{\circ} \mathrm{C}$. Enrichment in $\mathrm{Fe}$ and $\mathrm{Ni}$ is the main feature that distinguishes the UR17/2 olivine from other mantle-derived olivine. Composition of the UR17/2 olivine and host harzburgite indicates an influence of $T, P$, the oxygen fugacity and composition of parent magma on the partition coefficients of Fe and Ni. Composition and structure (degree of polymerization) of magma are the main factors responsible for the olivine enrichment by iron and nickel.
\end{abstract}

Keywords: olivine, iron- and nickel enrichment, harzburgite, Archaean, Ukrainian Shield.

Cite: Lobach-Zhuchenko, S.B., Egorova, Yu.S., Skublov, S.G., Sukach, V.V., Galankina O.L. (2021), Iron- and Nickel Enriched Olivine from Phlogopite Harzburgite of the Bug Granulite Complex (Ukrainian Shield). Mineral. Journ. (Ukraine), Vol. 43, No. 1, pp. 16-24. https://doi.org/10.15407/mineraljournal.43.01.016 
Introduction. Olivine is one of the major rockforming mineral of igneous rocks and one of the most abundant minerals of on our planet. Due to well-known relationships between composition and $T, P$ and oxygen fugacity parameters of crystallization, olivine is the most important indicator of petrological processes [17, 30, 47 and others]. In this study, we consider olivine from Archaean Spl-bearing phlogopite harzburgite (UR17/2) which has unusual composition: increased content of Fayalite $(\mathrm{Fa})$-end-member and a high content of $\mathrm{Ni}$; this composition is not common for olivine of ultramafic rocks [17].

The purpose of the study is to reveal possible petrological conditions of the iron- and nickelenriched olivine formation from the phlogopite harzburgite of the Bug granulite complex on the base of a detailed investigation of the olivine composition, including minor, trace and rare earth elements.

A brief description of Spl-bearing phlogopite harzburgite UR17/2. Spinel-bearing phlogopite harzburgite composes a small lenticular inclusion within gneissic enderbite of the Bug granulite complex in Odessa quarry located on the right bank of the South Bug river (N 49 $13^{\prime} 56^{\prime \prime}$; E 29 $9^{\circ} 59^{\prime} 13.5^{\prime \prime}$ ). Structural observations and a hybrid contact with the host enderbite suggest the intrusive nature of the UR17/2 harzburgite [29]. The UR17/2 lens is a fragment of a deformed dike. U-Pb (SIMS SHRIMP II) zircon age of the UR17/2 inclusion is $2814 \pm 51 \mathrm{Ma}$ [29]; the age of the host gneissic enderbites is much older $-3.60-3.75 \mathrm{Ga}[3,7,25$, $28,44]$. The inclusion of the Spl-bearing phlogopite harzburgite has a thin $(8-10 \mathrm{~cm})$ phlogopite orthopyroxenite border on a contact with the enderbite. The upper part of the lens metamorphosed to Pgs-Pl orthopyroxenite (Fig. 1 in [29]). The modal composition of the UR17/2 harzburgite is following: $\mathrm{Ol}-69 \%$, \#mg 0.85; Opx $-18 \%$, \#mg 0.86; Cpx - 3\%, \#mg 0.92; Phl - 9\%, \#mg 0.92;
Spl $-1 \%$ and minor sulfides, Zrn, Srp, Mag, Carb, Ap. Sulfide content is $<1 \%$ and therefore does not particularly affect the nickel balance.

Analytical techniques. The major element composition of olivine was determined by a scanning electron microscope equipped with an energy dispersive system (SEM-EDS) as well as electron probe microanalysis (EPMA) at the Institute of Precambrian Geology and Geochronology of Russian Academy of Sciences. SEM-EDS analyses were obtained using a scanning electron microscope JEOL JSM-6510 LA with an energy dispersive system JED-2200. The operating conditions were $20 \mathrm{kV}$ accelerating voltage, a beam current of $1.5 \mathrm{nA}$, and a beam of 1-2 $\mu \mathrm{m}$ in diameter. EPMA measurements were conducted on a JXA- 8230 with two-wavelength dispersive spectrometers, using acceleration voltage of $20 \mathrm{kV}$ and a sample current of 20 nA. Corrections for matrix effects were calculated using the ZAF method. The standards for Xray microanalysis M.A.C. Ltd.: olivine ( $\mathrm{Si}$ and $\mathrm{Mg}$ ), olivine-hortonolite $(\mathrm{Fe})$, orthoclase $(\mathrm{Al})$, diopside (Ca), spessartine ( $\mathrm{Mn})$, $\mathrm{TiO}$, pure metals $\mathrm{Cr}$ and $\mathrm{Ni}$. The results are given in Table $1 . \mathrm{FeO}$ and $\mathrm{MgO}$ contents obtained using SEM-EDS and EPMA are identical.

Measurements of trace elements in the olivine were conducted at the Yaroslavl branch of the Institute of Physics and Technology of Russian Academy of Sciences using a Cameca IMS-4f ion microprobe. Analytical procedures are mainly described in $[2,36]$. The size of the analytical crater was about $20 \mu \mathrm{m}$. Each analysis was averaged over 3 cycles of measurements. Concentrations of trace elements were calculated from the normalized to ${ }^{30} \mathrm{Si}^{+}$secondary ion intensities using calibration curves based on a set of reference glasses [19]. Particularly, a NIST-610 reference glass [40] was used as a daily monitor for trace element analyses. Accuracy of the trace element measurements is up to $10 \%$ for concentrations higher than $1 \mathrm{ppm}$ and up

Table 1. Average concentrations of major and minor elements in olivine of the spinel-bearing phlogopite harzburgite UR17/2

\begin{tabular}{|l|c|c|c|c|c|c|c|c|c|c|}
\hline \multicolumn{1}{|c|}{ Sample } & $n$ & $\mathrm{Fo}$ & $\mathrm{SiO}_{2}$ & $\mathrm{TiO}_{2}$ & $\mathrm{Al}_{2} \mathrm{O}_{3}$ & $\mathrm{FeO}$ & $\mathrm{Cr}_{2} \mathrm{O}_{3}$ & $\mathrm{MnO}$ & $\mathrm{MgO}$ & $\mathrm{NiO}$ \\
\hline $\mathrm{UR} 17 / 2 *$ & 47 & 86 & 40.03 & b.d.l. & b.d.1. & 13.66 & b.d.l. & 0.17 & 45.77 & b.d.1. \\
UR17/2-2I** & 11 & 86 & 40.36 & b.d.l. & b.d.l. & 13.66 & b.d.l. & 0.20 & 45.64 & 0.50 \\
UR17/2-2II** & 13 & 86 & 40.76 & b.d.l. & b.d.l. & 13.72 & b.d.l. & 0.20 & 45.55 & 0.50 \\
\hline
\end{tabular}

* - measurements were carried out in five harzburgite samples (UR17/2 UR17/2-2b, UR17/2-2v, UR17/2-2I, UR17/22II) by the SEM-EDS method; ** — measurements were made on an electron probe microanalyzer, $n$ - amount of measured points, b.d.l. - below the sensitivity threshold of the method. 

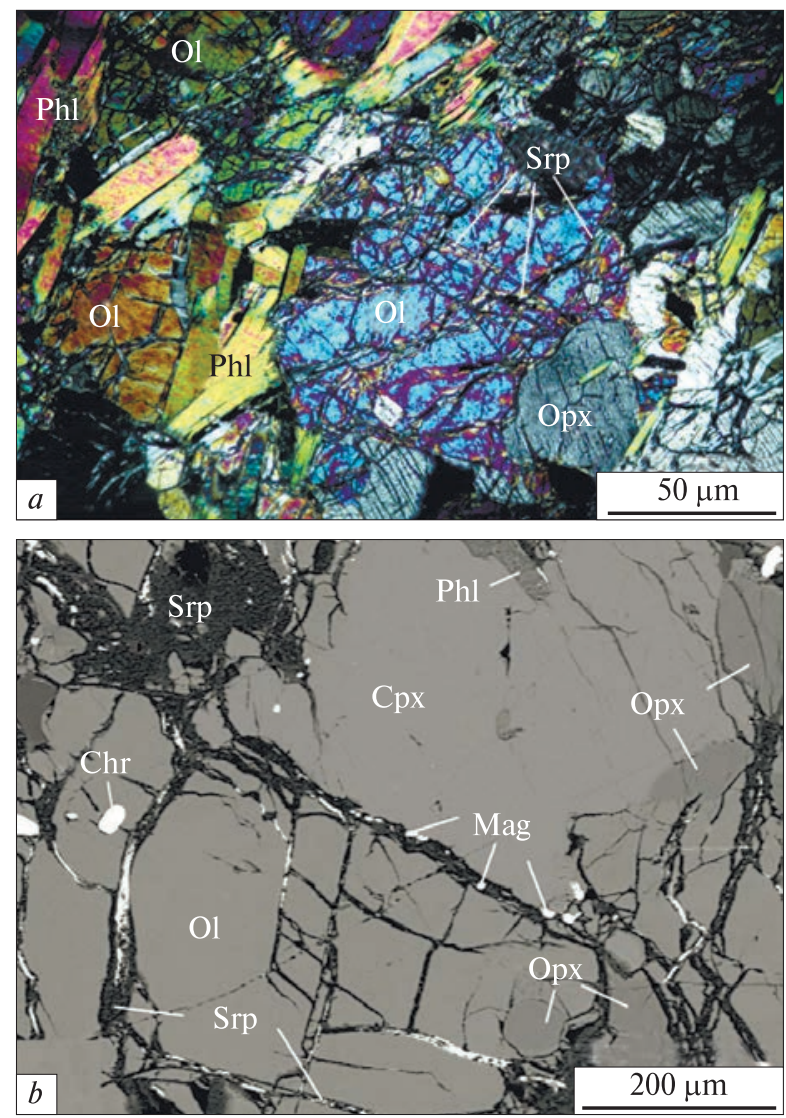

Fig. 1. (a) Thin section image of sample UR17/2-2I cracks in olivine and pyroxenes. (b) BSE-image of the UR17/2 harzburgite the development of serpentine and magnetite along cracks in olivine

to $20 \%$ for the concentration range $0.1-1 \mathrm{ppm}$, respectively. The measurements were made for 5 grains extracted from the rock (Table 2, 1-5) and for 4 olivine grains in a transparent-polished thinsection (Table 2, 6-9).

Results. 1. Olivine morphology. The olivine forms large grains (up to $1 \mathrm{~mm}$ ) with rare spinel (chromite) inclusions; the grains are fractured. Along with the net of cracks, olivine is replaced by serpentine and magnetite, the serpentinization is rather weak (Fig. 1). The trace of deformation is also seen in pyroxene and phlogopite. Here and there phlogopite laths flow around the olivine grains.

2. Composition of olivine: $\mathrm{Fe} / \mathrm{Mg}$ ratio. The olivine composition was measured at 47 points across five samples of the UR17/2 harzburgite by SEMEDS method and two samples by EPMA method. The olivine has a homogeneous chemical composition: $\mathrm{MgO}-45.20-45.64$ wt.\%, $\mathrm{FeO}-13.66-$ 14.23 wt. $\%, \mathrm{Fo}_{85-86}$ and the constant $\mathrm{Fe} / \mathrm{Mg}$ ratio (Table 1). Elevated content of fayalite molecule (14-15\%) is not common for mantle olivine and its derivatives [17 and references therein].
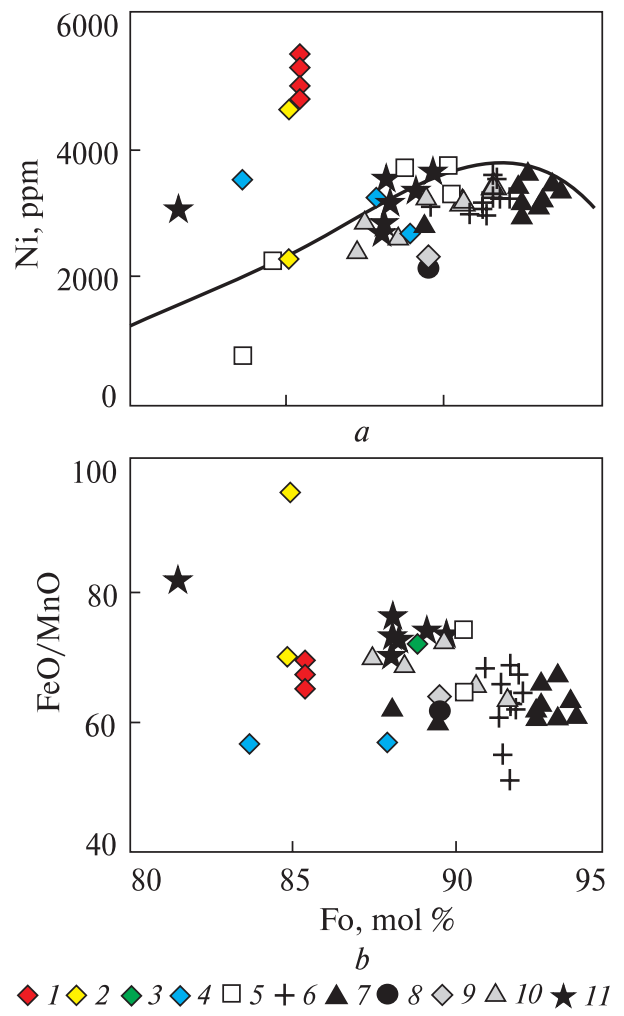

Fig. 2. Fo vs Ni content ( $a$ ) and $\mathrm{Fo}$ vs $\mathrm{FeO} / \mathrm{MnO}$ ratio $(b)$ in the UR17/2 olivine (1) and in olivine of the other objects: 2 - average values of ultramafic enclaves of the Bug complex (UR22/12, UR150); 3 - average value $(n=19)$ of phlogopite harzburgite of the Nemirovskaja intrusion [48]; 4 - Aleksandrovskaja intrusion from Middle Dnieper province of the Ukrainian Shield [42];5- ultramafic enclaves in gneisses, South East Greenland [13]; 6 peridotite enclaves in alkaline basalts [50]; 7 - komatiites of the greenstone belts of Canada and South Africa [39, 45]; 8 - MORB; 9 - Islandian lava (the lithosphere thickness less $70 \mathrm{~km}) ; 10$ - LIP in Pacifik and Atlantic islands, LIP of China (the lithosphere thickness more $70 \mathrm{~km}$ ); $11-$ picrites of Hawaiian islands and LIP of the Norilsk area. 8-11 - after [45]. The line in Fig. (a) for calculated olivine compositions from olivine-fractionated derivative liquids with $30 \% \mathrm{MgO}$ after [16]

3. Trace elements. Trace elements in olivine can be divided into three groups depending on their compatibility in olivine [8].

Group 1: $\mathrm{Mn}, \mathrm{Ni}, \mathrm{Co}$. Olivine is the main concentrator of these elements. The $\mathrm{MnO}$ content in the UR17/2 olivine ( $0.2 \mathrm{wt} . \%$, Table 1$)$ is slightly higher than in olivine of upper mantle xenoliths from alkaline basalts (0.12-0.14 wt.\%, [50]). On the other hand, the $\mathrm{Fe} / \mathrm{Mn}$ ratio 68.3-68.6 (Table 1) corresponds to that in olivine from xenoliths of spinel lherzolites and corresponds to the ratio (70-60) in olivine of peridotites in general [16]. The specific feature of the UR17/2 olivine is the ele- 
vated $\mathrm{Ni}$ content (Tables 1, 2), which varies from $4730 \mathrm{ppm}$ in the olivine from the harzburgite inclusion center to $5612 \mathrm{ppm}$ in the olivine, located closer to the contact with the orthopyroxenite border. The average Ni content measured in grains by the SIMS method is 5206 ppm (Table 2). Direct dependence of $\mathrm{Ni}$ content in olivine on $\mathrm{MgO}$ content in the melt $\left(\mathrm{D}_{\mathrm{Ni}}{ }^{\mathrm{Ol} / \mathrm{m}}\right)$ has been established [17]. The inverse relationship takes place in the UR17/2 harzburgite: the observed $\mathrm{Ni}$ content is inconsistent with its low magnesia (Fig. 2). The $100 \mathrm{Ni} / \mathrm{Mg}$ ratio (1.89) in the UR17/2 olivine is higher than that in olivine of peridotite xenoliths (1.05) from alkaline basalts [50] and higher than in olivine of oceanic basalts (0.75-1.15; [50]). The Co content in the UR17/2 olivine also increases from the harzburgite inclusion center (157 ppm, Table 1) to the border with the hybrid orthopyroxenite rim (236 ppm). These values are higher than in olivine of mantle rocks (105 ppm [8]) and close to that in olivine of mantle xenoliths from alkaline basalts (140-150 ppm; [50]). The Co content in the whole- rock UR17/2 (142-184 ppm [17]) is also higher than that in PM. Accordingly, the Ni/Co ratio (2837 ) in the UR17/2 is higher than the ratios in chondrites and BSE (20-22) [45].

Group 2: $\mathbf{C a}, \mathbf{A l}, \mathbf{C r}, \mathbf{V}$. The Ca content in the UR17/2 olivine varies insignificantly - from 3328 to $4312 \mathrm{ppm}$ (Table 2), the average value $3774 \mathrm{ppm}$. It is some higher than the Ca content (0.11-0.17 wt.\% CaO) in olivine of mantle xenoliths from alkaline basalts [50]. The Al content (56.7-92.8 ppm, Table 2) is close to that in olivine from mantle xenoliths. The crystallization temperature of olivine was calculated using an Al-in-olivine thermometer [6] and is $\sim 900{ }^{\circ} \mathrm{C}$. The $\mathrm{Ca} / \mathrm{Al}$ ratio (37-74) is close to that in olivine of peridotite xenoliths and significantly higher than in olivine of oceanic basalts [45]. The average $\mathrm{Cr}$ content in the UR17/2 olivine (388 ppm, Table 2) is close to that in olivine from oceanic basalts (MORB), and less than that in olivine of interplate basalts (OIB, LIP) [45] and mantle xenoliths [50]. The $\mathrm{V}$ content in the olivine (average $13.5 \mathrm{ppm}$,

Table 2. Concentrations of trace elements and REE in olivine of the spinel-bearing phlogopite harzburgite UR17/2

\begin{tabular}{|c|c|c|c|c|c|c|c|c|c|}
\hline Order number & 1 & 2 & 3 & 4 & 5 & 6 & 7 & 8 & 9 \\
\hline Grain & 1 & 2 & 5 & 23 & 25 & 1 & 2 & 3 & 4 \\
\hline $\mathrm{Al}$ & 92.8 & 63.7 & 56.7 & 58.5 & 76.1 & nd & nd & nd & nd \\
\hline $\mathrm{Ca}$ & 3419 & 3328 & 3894 & 4312 & 3915 & nd & nd & nd & nd \\
\hline $\mathrm{Ti}$ & 20.4 & 22.3 & 27.1 & 24.2 & 28.9 & 10.4 & 16.4 & 23.4 & 13.9 \\
\hline V & 6.42 & 13.0 & 14.4 & 18.9 & 14.9 & 11.1 & 12.8 & 12.4 & 10.4 \\
\hline $\mathrm{Cr}$ & 336 & 349 & 405 & 454 & 394 & 347 & 468 & 413 & 339 \\
\hline $\mathrm{Ni}$ & 4730 & 5575 & 4858 & 5149 & 5612 & nd & nd & nd & nd \\
\hline $\mathrm{Rb}$ & 1.79 & 2.30 & 2.08 & 2.31 & 2.72 & nd & nd & nd & nd \\
\hline $\mathrm{Sr}$ & 0.87 & 1.02 & 1.09 & 1.45 & 1.51 & 2.35 & 2.63 & 1.16 & 2.60 \\
\hline $\mathrm{Y}$ & 0.049 & 0.117 & 0.134 & 0.494 & 0.082 & 0.179 & 0.119 & 0.118 & 0.257 \\
\hline $\mathrm{Zr}$ & 0.366 & 0.456 & 0.321 & 0.733 & 0.325 & 0.596 & 0.545 & 0.359 & 0.597 \\
\hline $\mathrm{Nb}$ & 0.025 & 0.024 & 0.014 & 0.033 & 0.034 & 0.023 & 0.027 & 0.018 & 0.032 \\
\hline $\mathrm{Ba}$ & 0.075 & 0.158 & 0.179 & 0.379 & 0.269 & nd & nd & nd & nd \\
\hline Hf & 0.051 & b.d.l. & b.d.l. & 0.034 & 0.055 & nd & nd & nd & nd \\
\hline $\mathrm{La}$ & 0.017 & 0.034 & 0.012 & 0.315 & 0.022 & 0.052 & 0.011 & 0.016 & 0.031 \\
\hline $\mathrm{Ce}$ & 0.027 & 0.101 & 0.015 & 0.464 & 0.040 & 0.283 & 0.182 & 0.088 & 0.224 \\
\hline $\operatorname{Pr}$ & b.d.l. & 0.007 & 0.006 & 0.034 & b.d.l. & nd & nd & nd & nd \\
\hline $\mathrm{Nd}$ & b.d.l. & b.d.l. & b.d.l. & 0.156 & b.d.l. & b.d.l. & 0.057 & 0.031 & 0.070 \\
\hline $\mathrm{Sm}$ & b.d.l. & 0.038 & b.d.l. & 0.041 & b.d.l. & 0.014 & 0.009 & 0.013 & 0.038 \\
\hline $\mathrm{Eu}$ & 0.022 & 0.005 & 0.005 & 0.013 & 0.008 & 0.003 & 0.006 & 0.007 & 0.005 \\
\hline $\mathrm{Gd}$ & b.d.1. & 0.012 & b.d.l. & 0.104 & 0.027 & 0.035 & 0.013 & 0.022 & 0.024 \\
\hline Dy & b.d.l. & 0.023 & 0.018 & 0.057 & 0.018 & 0.020 & b.d.l. & b.d.1. & 0.021 \\
\hline $\mathrm{Er}$ & b.d.l. & 0.033 & 0.021 & 0.027 & 0.031 & 0.020 & b.d.l. & 0.062 & 0.031 \\
\hline $\mathrm{Yb}$ & 0.031 & 0.048 & 0.060 & 0.155 & 0.038 & 0.015 & 0.046 & 0.056 & 0.064 \\
\hline $\mathrm{Lu}$ & 0.010 & 0.011 & 0.007 & 0.017 & 0.011 & nd & nd & nd & nd \\
\hline
\end{tabular}

N o t e. b.d.l. - below the sensitivity threshold of the method, nd - not determined. 


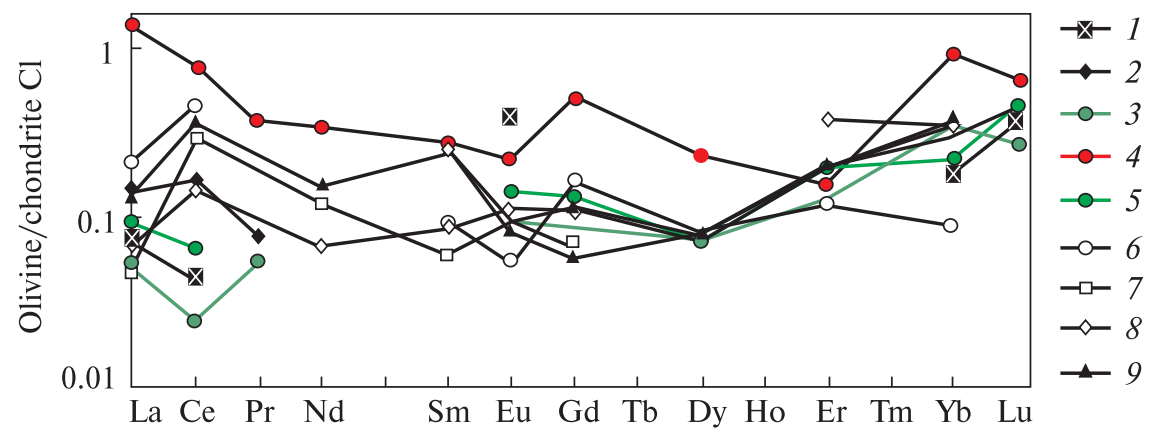

Fig. 3. Chondrite-normalized REE patterns for olivine from the spinel-bearing phlogopite harzburgite UR17/2 (normalization factors from [46]). The numbers in the legend correspond to the numbers of the analyzes in the Table 2
Table 2) is two times more than in olivine from mantle xenoliths. It corresponds to the higher iron content in the UR17/2 olivine.

Group 3: Ti, Zr, Nb, Y. The Ti content in the olivine is low (average value 20.6 ppm; Table 2) and corresponds to that in the olivine of mantle xenoliths. The $\mathrm{Zr}$ content in olivine is $0.32-0.60 \mathrm{ppm}$, the average $\mathrm{Nb}$ content is $0.03 \mathrm{ppm}$ (Table 2); these values are an order of magnitude higher than the $\mathrm{Zr}$ and $\mathrm{Nb}$ contents in olivine of mantle xenoliths from alkaline basalts. The $\mathrm{Y}$ content in the olivine varies from 0.05 to $0.26 \mathrm{ppm}$, excluding the grain 23 (Table 2). On the whole, the Y content corresponds to that in olivine of mantle xenoliths (average 0.052 ppm; [50]).

4. Rare Earth Elements. REE are measured for 9 olivine grains. Eight grains have a small total REE (0.1-0.5 ppm), flat patterns of L- and MREE with a slight increase in HREE (average $(\mathrm{La} / \mathrm{Yb})_{n}=$ $=0.56$, Table 2). The grain 23 is distinguished by increased REE concentrations (Table 2). This grain has a higher degree of fractionation: $(\mathrm{La} / \mathrm{Yb})_{n}=$ $=1.46$ and has higher $\mathrm{Y}, \mathrm{Zr}$, Nb contents in comparison with other grains. The REE patterns in olivine grains 1-5 (Fig. 3) is close to the second type of REE patterns identified for olivine of deep xenoliths [26]. The REE contents measured in thin sections (6-9, Table 2) are characterized by flat patterns (Fig. 3). Thus, the UR17/2 olivine is poor in REE compared to chondrite CI; however, the UR17/2 olivine has increased abundances of all REE relative to olivine from xenoliths of upper mantle peridotites [50].

Discussion. 1. Iron-enrichment of olivine. The UR17/2 harzburgite inclusion is located in gneissic enderbites that have experienced multiple, including granulite, metamorphism. In this regard, an important point is to determine the contribution of metamorphism to the olivine composition.

Metamorphic olivine is formed during dehydration of serpentinites and is usually represented by large neoblasts [9, 34]. It differs significantly from magmatic olivine in high titanium (up to 0.86 wt.\%) and some other elements, including Zr (0.9-2 ppm). The UR17/2 olivine has different morphological relationships with serpentine (Fig. 1, $a, b$ ) and significantly lower concentrations of $\mathrm{Ti}$ and $\mathrm{Zr}$ (Tables 1 and 2). Increased incompatible elements (LREE, Ba) contents in the olivine grain 23 (Table 2) indicate metasomatic alteration, but it has a $\mathrm{Ti}$ and $\mathrm{Zr}$ concentration of magmatic olivine. Thus, the UR17/2 olivine, both in morphology and composition, corresponds to magmatic olivine with a slight influence on metasomatic processes.

The olivine with $14-15 \%$ Fa end-member from the UR17/2 harzburgite does not correspond to the most compositions of olivine from basic-ultrabasic rocks: mantle xenoliths, orogenic peridotites of the Alpine belt, abyssal peridotites, kimberlites and basalts of the ocean floor, the magnesium number of which is generally within 89-92 [17]. Olivine from peridotite xenoliths in kimberlites representing the subcontinental lithospheric mantle (SCLM) is also more magnesian [43 and references therein].

It was found that the Fo content in olivine decreases with time - from the Achaean (Fo - 91.593.5) to the Proterozoic (Fo - 91-92.2), to the Phanerozoic (Fo - 89-91.7) [14]. The UR17/2 olivine has a \#mg value than olivine from Phanerozoic ultramafic rock. The increased iron content in olivine is a characteristic of many mafic and ultramafic rocks in the Ukrainian Shield. The olivine composition (Fa end-member) of ultramafic rocks of the Ukrainian Shield varies from 5.6 to $54.5 \%$, the average Fa content in olivine is $12.9 \%[12,21]$. The average content of Fa end-member for duniteharzburgite, gabbro-peridotite and dunite-gabbronorite are $12.88,19.24 \%$ and $16.28 \%$ respectively $[11,18,21,35]$. Olivine in peridotite inclusions of the Bug granulite complex - contains 16-20\% Fa end-member [29]. Olivine with the $25 \%$ Fa endmember is present in the gabbro-wehrlite complex [12]. The ultramafic lithologies of the gabbro-an- 
orthosite complex contain hyalosiderite and hortonolith [12]. There is high iron olivine (up to 50\% Fa end-member and more) in the gabbro-syenite and alkaline-ultramafic-carbonatite complexes [23].

The partitioning of iron between olivine and melt $\left(\mathrm{D}_{\mathrm{Fe}}{ }^{\text {ol-melt }}\right)$ depends on the $\mathrm{FeO}$ content in the melt, $T, P$ and $f_{\mathrm{O}_{2}}[4,17,30,49]$. The influence of melt composition and structure (degree of polymerization) on $\mathrm{D}_{\mathrm{Fe}}{ }^{\text {ol-melt }}$ was shown in experiments carried out at constant pressure, temperature and oxygen fugacity [24]. The lower \#mg of the UR17/2 olivine was influenced by whole-rock composition. The harzburgite UR17/2 has values of \#mg: 86-84 [29], like many other mafic and ultramafic rocks of the Sarmatian craton. Kaapvaal [15] and Slave [22] cratons contain single xenoliths of mantle peridotites with a similar lower \#mg and, accordingly, with iron-rich olivine (Fo 83-89). These xenoliths compositions are consistent with the results on ultramafic rocks of the Ukrainian Shield and confirm the assumption about the heterogeneity of the $\mathrm{FeO} / \mathrm{MgO}$ ratio in SCLM beneath this fragment of the East European Platform.

Temperature, pressure and $f_{\mathrm{O}_{2}}$ have a negative correlation with $\mathrm{D}_{\mathrm{Fe}}$ ol-melt $[4,30]$. The dyke-shaped harzburgite indicates moderate pressure during crystallization; the temperature calculated for the UR17/2 olivine is $\sim 900{ }^{\circ} \mathrm{C}$. The oxygen fugacity of the melt affects the $\mathrm{Fe}^{+3} / \Sigma \mathrm{Fe}$ ratio in the rock $[4,5,32,38]$. The $\mathrm{Fe}_{2} \mathrm{O}_{3} / \mathrm{FeO}+\mathrm{Fe}_{2} \mathrm{O}_{3}$ ratio in the harzburgite UR17/2 is low (0.27-0.36), which may indicate crystallization of the harzburgite at moderate $f_{\mathrm{O}_{2}}$ conditions. Thus, the increased iron content of the UR17/2 olivine could be influenced by low temperature and pressure, moderate oxygen fugacity.

2. Nickel-enrichment of olivine. High nickel content in the olivine UR17/2 (Table 2) is inconsistent with its high iron content (Fo 86-85\%). Partition coefficient of $\mathrm{Ni}$ between olivine and melt $\left(\mathrm{D}_{\mathrm{Ni}} \mathrm{Ol} /\right.$ melt) is controlled by $\mathrm{T}, \mathrm{P}, f_{\mathrm{O}_{2}}$ and the nickel content in the source [19, 16, 27, 30, 45]. The influence of melt composition and structure (degree of polymerization) on $\mathrm{D}_{\mathrm{Ni}}$ Ol/melt was shown in experiments at constant pressure, temperature, and oxygen fugacity [24]. A quantitative relationship between $\mathrm{D}_{\mathrm{Ni}} \mathrm{Ol} /$ melt and rock composition was also shown by [27]. An inverse correlation has been established between $\mathrm{D}_{\mathrm{Ni}} \mathrm{Ol} /$ melt and the $\mathrm{MgO}$ content in the melt [17]. As shown by [16, 17], the dependence of the Ni content and \#mg is strictly legal and forms a curve according to which olivine of peridotites has a Ni content of about 3000 ppm (Fig. 2, a). The
UR17/2 olivine (Fig. 2, $a$ ) is located out of the curve and is closer to the olivine from the Hawaiian picrites (Fig. 12, $b$ in [16]), differing from the latter in the $\mathrm{Fe} / \mathrm{Mn}$ ratio.

The high nickel content in the UR17/2 olivine is due to high nickel content in the host harzburgite (3700 ppm, [29]), which exceeds its concentration in the primitive mantle. The alkalinity of the melt also has a great influence on the $\mathrm{D}_{\mathrm{Ni}} \mathrm{Ol} /$ melt value in highly alkaline melts $\mathrm{D}_{\mathrm{Ni}}{ }^{\mathrm{Ol} / \text { melt }}$ reaches $30-90$ [13]. The UR17/2 harzburgite contains about 2 wt. $\% \mathrm{~K}_{2} \mathrm{O}$ and belongs to subalkaline ultramafic rocks [29]. The increased alkalinity of the melt likely contributed to the high $\mathrm{D}_{\mathrm{Ni}} \mathrm{Ol} /$ melt value [10]. Since $\mathrm{D}_{\mathrm{Ni}} \mathrm{Ol} / \mathrm{melt}$ value has an inverse correlation with the crystallization temperature and pressure [27], it can be assumed that the low pressure and temperature $\left(\sim 900{ }^{\circ} \mathrm{C}\right)$, along with the high contents of nickel and $\mathrm{K}_{2} \mathrm{O}$ in the melt, influenced the high contents of nickel in the UR17/2 olivine.

3. Models considering the increased iron and nickel content in olivine. The models are mainly based on the analysis of olivine from various oceanic basalts, to a lesser extent, mantle inclusions. Despite the limited amount of data, the homogeneity of the UR17/2 olivine composition makes it possible to compare it with olivine from other objects and to analyze the proposed models.

Comparison with mantle xenoliths. There is a limited amount of data on the content of trace elements in olivine from mantle xenoliths of Achaean cratons. A wide range of geochemical data is available for peridotite xenoliths in alkaline basalts from subcontinental lithospheric mantle of Central Europe [50]. Comparison of the composition of olivine from the UR17/2 harzburgite and the xenoliths generally demonstrates their similarity. The main differences are as follows: the UR17/2 olivine is more ferrous (Fig. 2, a), contains more Al, $\mathrm{Ni}, \mathrm{V}$, as well as HREE, $\mathrm{Sr}, \mathrm{Zr}$ and $\mathrm{Nb}$; it contains less of $\mathrm{Cr}$, $\mathrm{Ti}$, and $\mathrm{Mn}$, but close values of $\mathrm{FeO} / \mathrm{MnO}$ ratio (Fig. 2, b). The observed difference may reflect the difference in composition of the Achaean mantle of the Ukrainian Shield and the mantle beneath Central Europe, as it is shown for other cratons [31, 49].

Comparison with ocean basalts and existing models. Analysis of a large amount of data on the composition of olivine from basalts: MORB, OIB, LIP $[17,37,45]$ indicates the highest nickel concentrations and the $\mathrm{Fe} / \mathrm{Mn}$ ratio (higher than that of the mantle and chondrites) in olivine from picrites of the Hawaiian Islands, as well as picrites of the Gud- 
chikhinskaya Formation in the Norilsk region (Fig. 2, $a, b$ ). Based on the data on basalts, the following models have been proposed to explain the high $\mathrm{Fe}$ and $\mathrm{Ni}$ contents in olivine. The excess of $\mathrm{Ni}$ and the increased $\mathrm{Fe} / \mathrm{Mn}$ ratio in the olivine from Hawaii is explained by the participation of assimilated pyroxenite in the mantle source of the basalts [45]. By this model, a source of picrites corresponds to basic rock $\left(\mathrm{SiO}_{2}\right.$ about 48-50 wt.\%). Since the source of the UR17/2 harzburgite was peridotite [1], this model is not suitable for explaining the peculiarities of the UR17/2 olivine composition. According to other studies [27, 33, $37,38]$, the excess $\mathrm{Ni}$ in olivine from Hawaii may be due to high pressure rather than a contribution to the source of pyroxenite. This conclusion is confirmed by the data on basalts in general [45]: the average $\mathrm{Ni}$ content in olivine from areas with a lithosphere thickness of less than $70 \mathrm{~km}$ is $2300 \mathrm{ppm}$, and from areas with a lithosphere thickness of more than $70 \mathrm{~km}$, more than $3000 \mathrm{ppm}$ (Fig. 2,a). Another model considers an increase in the content of $\mathrm{Fe}$ and $\mathrm{Ni}$ in the rock and olivine as a result of the addition of material from the Earth's core to the mantle. This model is proven by calculations of the matter balance and the Re-Os isotope data carried out for the picrites of the Hawaiian Islands and the picrites of the Norilsk area [17, 41]. It is difficult to assess the applicability of this model to studied the UR17/2 harzburgite at this stage of research. The increased iron and nickel contents in the UR17/2 olivine is largely determined by the unusual nature of iron and nickel enrichment of the initial melt.

Conclusion. Olivine from the small inclusion of spinel-bearing phlogopite harzburgite in the $\mathrm{Pa}$ leoarchean gneissic enderbites (the Bug complex of the Ukrainian Shield) is magmatic in origin. The olivine has increased iron and nickel contents, which are not typical for olivine of mantle rocks and its ultramafic derivatives.

The main factors determining the geochemical features of the UR17/2 olivine are the composition of the initial melt (high iron and nickel contents and alkalinity) and the conditions of magma crystallization in the crust (relatively low temperature and pressure), which influenced the high $\mathrm{D}_{\mathrm{Ni}} \mathrm{Ol} /$ melt and $\mathrm{D}_{\mathrm{Fe}} \mathrm{Ol} / \mathrm{melt}$ values, as well as the structure of the melt, determined by the moderate $\mathrm{Fe}^{3+} / \Sigma \mathrm{Fe}$ ratio. Low REE contents in the studied olivine characterize the deep source of the initial melt of the phlogopite harzburgite.

Acknowledgements. This study was made in the framework of the State Task of the Institute of Precambrian Geology and Geochronology (projects no. FMNU-20190001; FMNU-2019-0002). We are grateful to L.M. Stepanyuk and V.V. Balagansky for their input in joint geological research and an anonymous reviewer for comments that helped to improve the manuscript. We wish to thank S.G. Simakin and E.V. Potapov (Valiev IPT RAS, Yaroslavl Branch) for their assistance in olivine study.

\section{REFERENCES}

1. Baltybaev, Sh.K., Lobach-Zhuchenko, S.B., Egorova, Yu.S., Balagansky, V.V., Galankina, O.L. and Yurchenko, A.V. (2018), Evolution of the substantial and isotopic composition of the Precambrian lithosphere, Vysshie uchebnye zavedeniya, St. Petersburg, pp. 193-212 [in Russian].

2. Batanova, V.G., Suhr, G. and Sobolev, A.V. (1998), Geochim. et Cosmochim. Acta, Vol. 62, pp. 853-866. https://doi. org/10.1016/s0016-7037(97)00384-0

3. Bibikova, E.V., Claesson, S., Fedotova, A.A., Stepanyuk, L.M., Shumlyanskyy, L.V., Kirnozova, T.I., Fugzan, M.M. and Il'insky, L.S. (2013), Geochem. Int. Vol. 51. pp. 87-108. https://doi.org/10.1134/S0016702913020031

4. Blundy, J., Melekhova, E., Ziberna, L., Humphreys, M.C.S., Cerantola, V., Brooker, R.A., McCammon, C.A., Pichavant, M. and Ulmer, P. (2020), Contribs Mineral. and Petrol., Vol. 175, Iss. 11. Art. number: 103. https://doi. org/10.1007/s00410-020-01736-7

5. Borisov, A., Behrens, H.H. and Holtz, F. (2018), Contribs Mineral. and Petrol. Vol. 173 (98), https://doi.org/10.1007/ s00410-018-1524-8

6. Bussweiler, Y., Brey, G.P., Pearson, D.G., Stachel, T., Stern R.A., Hardman, M.F., Kjatsgaard, B.A. and Jackson, S.E. (2017), Lithos, Vol. 272-273, pp. 301-314. https://doi.org/10.1016/j.lithos.2016.12.015

7. Claesson, S., Bibikova, E., Shumlyanskyy, L., Dhuime, B. and Hawkesworth, C.J. (2015), Geol. Soc. London. Spec. Publ., Vol. 389, pp. 227-259. https://doi.org/10.1144/SP389.9

8. De Hoog, J.C.M., Gall, L. and Cornell, D.H. (2010), Chem. Geol., Vol. 270, pp. 196-215. https://doi.org/10.1016/j. chemgeo.2009.11.017

9. De Hoog, J.C.M., Hattori, K. and Jung, H. (2014), Contribs Mineral. and Petrol., Vol. 167, No. 3, Art. number: 990. https://doi.org/10.1007/s00410-014-0990-X

10. Foley, S.F., Prelevic, D., Rehfeldt, T. and Jacob, D.E. (2013), Earth Planet. Sci. Lett., Vol. 363, pp. 181-191. https://doi. org/10.1007/s00410-014-0990-x 
11. Fomin, A.B. (1972), Dokl. AN USSR, Ser. B, No. 7, pp. 617-621 [in Russian].

12. Fomin, A.B., Kravchenko, G.L. and Litvin, A.L. (1980), Mineral. Journ. (Ukraine), Vol. 2, No. 1, Kyiv, UA, pp. 78-83 [in Russian].

13. Friend, C.R.L., Bennett, V.C. and Nutmann, A.P. (2002), Contribs Mineral. and Petrol. Vol. 143, pp. 71-92. https://doi. org/10.1007/s00410-001-0332-7

14. Griffin, W.L., Zhang, A., O’Reilly, S.Y. and Ryan, C.G. (1998), Structure and Evolution of the Australian Continent, DC: American Geophysical Union, Washington. Geodyn. Series. Vol. 26, pp. 1-25.

15. Gurney, J.J., Harte, B. and Cox, K.G. (1975), Phys. Chem. Earth., Vol. 9, pp. 507-523. https://doi.org/10.1016/00791946(75)90036-1

16. Hart, S.R. and Davis, K.E. (1978), Earth Planet. Sci. Lett., Vol. 40, pp. 203-219. https://doi.org/10.1016/0012821X(78)90091-2

17. Herzberg, C. (2011), J. Petrol., Vol. 52, pp. 113-146. https://doi.org/10.1093/petrology/egq075

18. Humayun, M., Qin, L. and Norman, M.D. (2004), Science, Vol. 306, pp. 91-94. https://doi.org/10.1126/science. 1101050

19. Ilvitsky, M.M. and Kolbantsev, R.V. (1968), Dokl. AN SSSR, Vol. 179, No. 6, pp. 1428-1431 [in Russian].

20. Jochum, K.P., Dingwell, D.B., Rocholl, A., Stoll, B., Hofmann, A.W., Becker, S., Besmehn, A., Besserte, D., Dietze, H.J., Dulski, P., Erzinger, J., Hellebrand, E., Hoppe, P., Horn, I., Janssens, K., Jenner, G.A., Klein, M., McDonough, W.F., Maetz, M., Mezger, K., Münker, C., Nikogosian, I.K., Pickhardt, C., Raczek, I., Rhede, D., Seufert, H.M., Simakin, S.G., Sobolev, A. V., Spettel, B., Straub, S., Vincze, L., Wallianos, A., Weckwerth, G., Weyer, S., Wolf, D. and Zimmer, M. (2007), Geostand. Geoanalyt. Res., Vol. 24, pp. 87-133.

21. Kanevsky, A.Ya. (1991), Geochemistry and Ore Formation, Vol. 18, Kyiv, UA, pp. 58-64 [in Russian].

22. Kopylova, M.G., Russell, J.K. and Cookenboo, H. (1999), J. Petrol., Vol. 40, pp. 79-104. https://doi.org/10.1093/ petroj/40.1.79

23. Kryvdik, S.G. (1997), Abstracts report Resp. sympos., Dnepropetrovsk, Nauk. dumka, Kyiv, UA, pp. 61-75 [in Russian].

24. Kushiro, I. and Mysen, B.O. (2002), Geochim. et Cosmochim. Acta, Vol. 66, pp. 2267-2272. https://doi.org/10.1016/ S0016-7037(01)00835-3

25. Lesnaya, I.M. (1988), Geochronology of charnockitoids of the Bug region, Nauk. dumka, Kyiv, UA, 133 p. [in Russian].

26. Lesnov, F.P. (2000), Proc. Russian Miner. Soc., No. 6, RU, pp. 88-103 [in Russian].

27. Li Ch. and Ripley, M. (2010), Chem. Geol., Vol. 275, pp. 99-104. https://doi.org/10.1016/j.chemgeo.2010.05.001

28. Lobach-Zhuchenko, S.B., Balagansky, V.V., Baltybaev, Sh.K., Stepanyuk, L.M., Ponomarenko, A.N., Lokhov, K.I., Koreshkova, M.Yu., Yurchenko, A.V., Egorova, Yu.S., Sukach, V.V., Berezhnaya, N.G. and Bogomolov, E.S. (2013), Mineral. Journ. (Ukraine), Vol. 35, No. 4, Kyiv, UA, pp. 86-98 [in Russian].

29. Lobach-Zhuchenko, S.B., Egorova, Yu.S., Baltybaev, Sh.K., Balaganskiy, V.V., Stepanyuk, L.M., Yurchenko, A.V., Galankina, O.L., Bogomolov, E.S. and Sukach, V.V. (2018), Evolution of the substantial and isotopic composition of the Precambrian lithosphere, Vysshie uchebnye zavedeniya, St. Petersburg, RU, pp. 144-169 [in Russian].

30. Mysen, B.O. (2006), Geochim. et Cosmochim. Acta, Vol. 70, pp. 3121-3138. https://doi.org/10.1016/j.gca.2006.03.014

31. Nikitina, L.P. and Babushkina, M.S. (2020), Proc. of XXI Int. conf. "Physic-chemical research in earth sciences", 2020, Moscow, RU, pp. 184-186 [in Russian].

32. Nikolaev, T.S., Borisov, A.A. and Ariskin, A.A. (1996), Geochem. Int., Vol. 34, No. 8, pp. 641-649.

33. Niu, Y., Wilson, M., Humphrteys, E.R. and O’Hata, M.J. (2011), J. Petrol., Vol. 52, pp. 1443-1468. https://doi. org/10.1093/petrology/egr030

34. Oliver, R.L. and Nesbitt, R.W. (1972), Contribs Mineral. and Petrol., Vol. 36, pp. 335-342. https://doi.org/10.1007/ BF00444340

35. Popovchenko, S.E. and Shukaylo, L.G. (2001), Mining and geological series, Iss. 32, DonNTU, Donetsk, UA [in Ukrainian].

36. Portnyagin, M., Almeev, R., Matveev, S. and Holtz, F. (2008), Earth Planet. Sci. Lett., Vol. 272, pp. 541-552. https:// doi.org/10.1016/j.epsl.2008.05.020

37. Putirka, K.D., Ryerson, F.J., Perfit, M. and Ridley, W.I. (2011), J. Petrol., Vol. 52, pp. 279-313. https://doi.org/10.1093/ petrology/egq080

38. Putirka, K. (2016), Amer. Miner., Vol. 101, pp. 819-840. https://doi.org/10.2138/am-2016-5402

39. Robin-Popieul, C.M., Arndt, N., Chauvel, C., Byerly, G.R., Sobolev, A.V. and Wilson, A.A. (2012), J. Petrol., Vol. 53, pp. 2191-2229. https://doi.org/10.1093/petrology/egs042

40. Rocholl, A.B.E., Simon, K., Jochum, K.P., Bruhn, F., Gehann, R., Kramar, U., Luecke, W., Molzahn, M., Pernicka, E., Seufert, M., Spettel, B. and Stummeier, J. (1997), Geostand. Newsl., Vol. 21, Iss. 1, pp. 101-114. https://doi. org/10.1111/j.1751-908X.1997.tb00537.x

41. Ryabchikov, I.D. (2003), Dokl. Earth Sci., Vol. 389, No. 3, pp. 437-439.

42. Samborskaya, I.A., Artemenko, G.V., Bondarenko, I.N. and Martynyuk, A.V. (2007), Proc. Voronezh State Univ. Ser. geol., No. 2, RU, pp. 94-104 [in Russian].

43. Sazonova, L.V., Nosova, A.A., Kargin, A.V. Borisovskiy, S.E., Abazova, Z.M., Griban', Y.G. and Tretyachenko, V.V. (2015), Petrology, Vol. 23, No. 3, pp. 227-258. https://doi.org/10.1134/S0869591115030054

44. Shumlyanskyy, L., Hawkesworth, C., Dhuime, B., Billström, K., Claesson, S. and Storey, C. (2015), Precam. Res. (2015), Vol. 260, pp. 39-54. https://doi.org/10.1016/j.precamres.2015.01.007 
45. Sobolev, A.V., Hofmann, A.W., Kuzmin, D.V., Yaxley, G.M., Arndt, N.T., Chung, S.-L., Danyushevsky, L.V., Elliott, T., Frey, F.A., Garcia, M.O., Gurenko, A.A., Kamenetsky, V.S., Kerr, A.C., Krivolutskaya, N.A., Matvienkov, V.V., Nikogosian, I.K., Rocholl, A., Sigurdsson, I.A., Sushchevskaya, N.M. and Teklay, M. (2007), Science, Vol. 316, pp. 412-417. https://doi.org/10.1126/science.1138113

46. Sun, S.S. and McDonough, W.F. (1989), Geol. Soc. London. Spec. Publ., Vol. 42, pp. 313-345. http://doi.org/10.1144/ GSL.SP.1989.042.01.19

47. Takahashi, E. (1978), Geochim. et Cosmochim. Acta, Vol. 42, pp. 1824-1844. https://doi.org/10.1016/0016-7037(78)90238-7

48. Tsymbal, S.N., Kanevsky, A.Ya. and Kryvdik, S.G. (1996), Mineral. Journ. (Ukraine), Vol. 18, No. 1, Kyiv, UA, pp. 3947 [in Russian].

49. Vrevskij, A.B., Glebovitskij, V.A., Goncharov, A.G., Nikitina, L.P. and Pushkarev, Yu.D. (2010), Vestnik Otdelenia nauk o Zemle RAN, Vol. 2, NZ6009. https://doi.org/10.2205/2010NZ000027

50. Witt-Eickschen, G. and O'Neil, H.St.C. (2005), Chem. Geol., Vol. 221, pp. 65-101. https://doi.org/10.1016/j.chemgeo. 2005.04.005

Received 12.12.2020

С.Б. Лобач-Жученко, д-р геол.-мін. наук, проф., гол. наук. співроб.

Інститут геології та геохронології докембрію РАН

199034, м. Санкт-Петербург, РФ, наб. Макарова, 2

E-mail: slobach-zhuchenko@mail.ru; ScopusID: 6601977762

Ю.С. Сгорова, канд. геол.-мін. наук, наук. співроб.

Інститут геології та геохронології докембрію РАН

199034, м. Санкт-Петербург, РФ, наб. Макарова, 2

E-mail: axохух2014@gmail.com; https://orcid.org/0000-0001-5008-6867

С.Г. Скублов, д-р геол.-мін. наук, проф., гол. наук. співроб.

Інститут геології та геохронології докембрію РАН

199034, м. Санкт-Петербург, РФ, наб. Макарова, 2

Санкт-Петербурзький гірничий університет

199106, м. Санкт-Петербург, РФ, ВО, 21 лінія, 2

E-mail: skublov@yandex.ru; ScopusID: 55918967400

B.В. Сукач, д-р геол. наук, зав. від.

Інститут геохімії, мінералогії та рудоутворення

ім. М.П. Семененка НАН України

03142, м. Київ, Україна, пр-т Акад. Палладіна, 34

E-mail: svital@ukr.net; ScopusID: 56287291600

О.Л. Галанкіна, канд. геол.-мін. наук, старш. наук. співроб.

Інститут геології та геохронології докембрію РАН

199034, м. Санкт-Петербург, РФ, наб. Макарова, 2

E-mail: galankinaol@mail.ru; ScopusID: 7801578217

ЗБАГАЧЕНИЙ ЗАЛІЗОМ І НІКЕЛЕМ ОЛІВІН ІЗ ФЛОГОПІТОВОГО
ГАРЦБУРГІТУ ПОБУЗЬКОГО КОМПЛЕКСУ УКРАЇНСЬКОГО ЩИТА

Вивчено хімічний склад олівіну із включення архейського шпінельвмісного флогопітового гарцбургіту (зразок $U R 17 / 2)$ в ендербіто-гнейсах побузького комплексу Українського щита. Гарцбургітове тіло має форму лінзи, що розглядається нами як фрагмент деформованої дайки. Інтрузивна природа цього включення підтверджується структурним співвідношенням та наявністю гібридної зони на контакті з вмісними ендербітами. Головні елементи олівіну визначені методами $S E M-E D S$ та $E P M A$, рідкісні та рідкісноземельні - методом SIMS. Олівін має постійний склад: $\mathrm{MgO}$ - 45,20-45,64 мас. \%, FeO - 13,66-14,23 мас. \%, Fo 86-85 \% і відношення Fe/Mn 68,3-68,6, яке відповідає такому ж відношенню в перидотитах (70-60). Вміст Ni в олівіні змінюється від 4730 до 5612 ppm, що вище вмісту $\mathrm{Ni}$ в олівіні мантійних перидотитів, а також високомагнезіальних ОIВ і пікритів Гавайських островів. Температура кристалізації олівіну, визначена за вмістом у ньому $\mathrm{Al}$, дорівнює $\sim 900{ }^{\circ} \mathrm{C}$. Середній вміст в олівіні $\mathrm{Ti}-20,6 \mathrm{ppm}, \mathrm{Nb}-0,03 \mathrm{ppm}, \mathrm{Zr}-0,32-0,60 \mathrm{ppm}$. Вміст $R E E$ характеризується низькими значеннями (в сумі $0,1-0,5$ ppm), що свідчить про глибинне джерело вихідного розплаву флогопітового гарцбургіту. Головними особливостями складу вивченого олівіну є збагачення залізом і нікелем, що є відмінним від олівінів порід, похідних мантії. Аналіз отриманих даних про склад олівіну у зразку $U R 17 / 2$ і склад вмісних гарцбургітів показав, що розподіл Fe i Ni між олівіном і породою залежить від температури, тиску, фугітивності кисню і складу вихідної магми (підвищений вміст і лужність заліза, високі концентрації нікелю). Важливими є також умови кристалізації магми в корі: відносно низькі температура і тиск, помірне відношення $\mathrm{Fe}^{3+} / \mathrm{Fe}^{2+}$.

Ключові слова: олівін, збагачення $\mathrm{Fe}$ i Ni, гарцбургіт, архей, Український щит. 